\title{
SPEAKER MEANING ATTRIBUTED TO THE TERMS SALVATION AND INSINDISO IN SELECTED MAINLINE AND INDEPENDENT CHURCH CONTEXTS
}

\author{
Nick Kerr and Frenette Southwood \\ Department of General Linguistics \\ Stellenbosch University
}

\begin{abstract}
This study was conducted to ascertain what meanings the terms salvation, saved, and their isiZulu equivalents have for some Zulu Christians. Semi-structured interviews were conducted with nine mother-tongue speakers of isiZulu varying in terms of age, gender, church affiliation and level of theological training. It transpired that both the English and isiZulu terms have undergone selective semantic narrowing: Apart from having their conventional meaning (pertaining to a personal acceptance of the redemptive work of Christ), these terms also imply for some Christians (specifically Evangelical and Pentecostal Zulus) an exclusive, validating spiritual experience precluding any involvement with ancestral practices. Consequently, one is viewed as saved only if one denounces certain apparently evil cultural practices, particularly those pertaining to ancestors. As other isiZuluspeaking Christians disagree with this narrowed meaning, and as mother-tongue speakers of English are generally unaware of it, indiscriminate use of these terms could lead to intercultural miscommunication of a complex nature.
\end{abstract}

Keywords: Salvation, Ukusindiswa, Insindiso, Zulu, Isizulu, Miscommunication

\section{Introduction}

In the course of his ministry as a priest in The Anglican Church of South Africa, the first author noticed that the English terms salvation and to be saved and their isizulu equivalents, namely insindiso and ukusindiswa, do not necessarily have the same meaning for all mother-tongue speakers of isiZulu in the Mooi River area in which he serves. Furthermore, it appeared that many of his isiZulu-speaking parishioners and acquaintances were dissatisfied with these terms. One of the reasons for the dissatisfaction appeared to be that, for certain isiZulu-speaking Christians (mostly Roman Catholics, 'Anglo-Catholic' Anglicans and members of some African Independent Churches in the geographical area in question) but not for English-speaking ones, the assimilation of cultural practices pertaining to ancestors into their world view has been seen as an acceptable synthesis of benign cultural and Christian elements. For the other group, consisting of Evangelical and Pentecostal Christians in the Mooi River area, the rejection of ancestral cultural practices had become a significant implied aspect of the meaning of salvation/insindiso, causing these terms to refer to the spiritual qualifications for being a member of certain church groupings rather than to what was perceived as 'core aspects' of salvation. ${ }^{1}$ There appeared

From the outset, we need to clarify that the interpretation of a term might differ from one sector of a denomination, diocese or archdiocese to the next, and that we by no means imply that all church groupings are homogenous in terms of the meaning attached to the terms salvation, to be saved, insindiso and ukusindiswa. 
to be the possibility of intercultural miscommunication between people who do not understand the cultural aspects related to these terms and those for whom they form part of their world view and culture. In this study, some of the popular meanings ascribed to the terms to be saved/ukusindiswa and saved (ones)/abasindisiwe were ascertained, based on interviews conducted with a limited number of isiZulu-speaking Christians of varying backgrounds.

In the next two sections, theological views on different aspects of salvation, as well as the different interpretations given to the terms salvation and (to be) saved, are discussed, respectively. Given the wide range of theological views and linguistic interpretations, it is understandable that different people may mean different things when they use these terms, even if these people belong to the same denomination and live in the same geographical area. The specific question which arose and which will be addressed in this study is whether or not the meaning of the term to be saved and its isiZulu translation ukusindiswa, as understood by a selection of isiZulu-speaking Christians, is unambiguous. If the term is found to be ambiguous, then this could be grounds for intercultural miscommunication, between isiZulu-English bilingual and English-speaking ${ }^{2}$ parishioners as well as between Christians of various ecclesiastical cultures.

\section{Theological Perspectives on Salvation Theological analysis}

When attempting to understand what is meant by salvation, it is not sufficient simply to state how the Bible uses the term, as each succeeding generation of Christians has interpreted and applied it in differing ways. Below, an exposition is given of various aspects of salvation.

\section{- The nature of salvation in Christ}

The nature of salvation in Christ has been understood in different manners during different periods of church history. Recent studies have emphasized the importance of contextualization and the idea of receptor-orientation of the Christian message. An example would be that those who are politically or spiritually oppressed would find the gospel message to be liberating politically, whereas those burdened by personal guilt would find salvation in forgiveness and pardon. McGrath (1997:412-413) puts forward several approaches to salvation, but emphasizes that, on their own, none would be fully constitutive of the Christian view of salvation and would severely limit the scope of the gospel message. Some of these approaches are discussed below.

Deification is an emphasis of the Eastern Christian tradition. It pertains to the notion that "God became human in order that humans might become God".

Another aspect of salvation is that of "righteousness in the sight of God" (McGrath 1997:414-415). Luther's question as to how he could find a gracious God has been the model for those who felt that sinners could not find acceptance from a righteous God. This

However, it should be noted that although this study was conducted in a certain geographical area, it does not mean that the opinions of those interviewed are necessarily representative of this area only. This is particularly the case for those with theological training, as they would have formulated their views on salvation and related matters over an extended period of time and in different theological and geographical contexts.

2 Throughout, we assume that typical white English-speaking Christians (to which group both of the authors belong) do not consider salvation to be a controversial term and that such Christians are generally unaware of the possibility that views on salvation can be divided into those of believers who adhere to cultural practices pertaining to their ancestors and those of believers who reject such practices. 
type of concern naturally used legal categories in relation to the issue of justification. For Luther, the gospel provided justifying righteousness to believers that would allow them entry into the presence of God without condemnation. Popular Protestantism gave great emphasis to this insight, especially in devotional writing and hymnology.

A further aspect of the nature of salvation can be found in the 'authentic human existence' which came through the existentialism of Martin Heidegger, protesting dehumanization in different forms. Heidegger first contrasted authentic and inauthentic existence (McGrath 1997:415), arguing that the New Testament spoke of these two modes of existence: The two options open to humanity are, firstly, the authentic or redeemed existence of faith in God and, secondly, an inauthentic existence of being oppressed by a purely material world. This approach has been criticized as being no more than a general philosophy of human existence with little relevance to the social aspects of the Christian gospel or the transcendent aspects of salvation (cf McGrath 1997:415).

Political liberation has been the strong theme of liberation theologians of Latin America, as seen in the title of Leonardo Boff's (1978) book Jesus Christ Liberator: A Critical Christology for Our Time. Likewise, black liberation theology was popularised in southern Africa in the early 1970s. In this region, liberation theology, supported by amongst others Allan Boesak, developed in parallel with the Black Consciousness Movement (Mukuka, n.d.), the latter being influential in South Africa and Namibia in terms of encouraging resistance to the apartheid system. As stated by Mukuka (n.d.), Black Consciousness was deeply rooted in Christianity, seeing that the Anglican Archbishop Robert Selby Taylor led a meeting out of which the University Christian Movement was said to be born, and that this movement later became the vehicle for Black Consciousness (Mukuka, n.d.). In liberation theology, salvation is seen in the context of the poverty and political struggles for social justice amongst the oppressed people of the world. This approach has been criticized as being confined to the purely political aspects of salvation (cf McGrath 1997:415-416).

Spiritual freedom is the theme of the Christus Victor approach to the death and resurrection of Jesus Christ. This emphasizes that Christ has won a victory over powers that enslave humanity, such as satanic oppression, evil spirits, fear of death, and the power of sin. Medieval theologians were drawn to this approach, as was Martin Luther. Some modern theologians have tended to dismiss views which emphasize belief in objective evil spirits or a personal devil. A reinterpretation has occurred, however, where these objective forces have become the subjective forces that enslave humanity.

\section{- The scope of salvation}

McGrath (1997:417-418) states that there are two approaches to the scope of salvation in Christ. The first approach is that of the universal saving will of God by which all are saved. Origen in the third century believed that this approach rightly denied any dualism which would allow the devil to reign over a realm separate from God, and the radical English scholar JAT Robinson believed that no one would ultimately be able to resist the love of God. The second approach is that salvation is possible only in and through Christ. Augustine, arguably the most influential father of the Western church, firmly upheld the belief that salvation was conditional on faith. 


\section{- The contribution of African theologians to understanding salvation}

The African theologian Mana (2002:3) proposes that the first area of study in the quest for salvation in Africa should be the tendency for Africans to diminish themselves personally, culturally and societally. The second area is that of the means employed in the struggle against social forces of destruction, the moral decay and the spiritual collapse brought about by supernatural oppressive forces, which require the urgent intervention of God and a christologically transforming dynamic which would enrich present day society. The third area of study in the quest for salvation would be a vision of the future which would provide the comprehensive renewal of society. Mana (2002:4) asks the important question as to how Jesus Christ can provide a foundation for a new meaning and a new destiny for African society.

Magesa (2004:142) emphasizes that the model for the Christian message is the incarnation of Christ in the Jewish culture, and therefore the message has to take root in all cultures in which it is proclaimed. He does, however, raise the question of how Christianity coming to Africa in its Western cultural trappings can contribute to the reshaping of African culture, adding that African Christians should not be alienated by being changed into Europeans or Americans. Another question raised is that of how African concepts of life and of God can contribute to and enrich Euro-American Christianity. According to Magesa (2002:142), an equal respect should be shown towards African identity and gospel identity, both 'having divine origin'.

Magesa (2004:142) also emphasizes that the liberation of the Christian message should include political, economic and social modes of existence so as to encourage African Christians to be fully African and fully Christian. He proposes that an important contribution to this liberation should take place through a process known as 'inculturation', which he states has taken place when Africans feel themselves affirmed as Africans in and by the Gospel message (Magesa 2004:145). Magesa (2004:240-241) sees in Roman Catholic spirituality with its veneration of the saints, an opportunity for African Christians to use ancestors in a similar way as intermediaries to approach God $^{3}$ (in this regard, see also Meiring 1996:15-16). He contrasts this approach with a traditional Protestant spirituality in which intermediaries play no part, as the believer is seen as having direct access to God. He concludes that Roman Catholic spirituality paves the way for an inclusive approach to the world view of African traditional religion.

Mazibuko in Gerloff (2003:221) attempts a creative response to the practice of ancestral veneration by developing a Christology of 'Christ our Ancestor'. Magesa (2004:260) quotes Nyamiti, the Tanzanian theologian, as the foremost proponent of this view on which the characteristics of an African ancestor can be applied to Christ: Firstly, both can be seen as sharing blood with their descendents, the African ancestors through generation and Christ through the incarnation. Secondly, both are seen to be sacred, possessing supernatural power and mediating between the visible world of human experience and the invisible world of spirits and God. Thirdly, it is believed that both are able to communicate with human beings in various ways, assisting them to live a moral life. Lastly, their life is seen as one of example: While Christ's life is far beyond all human ancestorship, it does express the African idea of relationship to the ancestors and vice versa. Nyamiti's

Note that attempts to reconcile Christian faith with traditional African cultural practices concerning the ancestors are not a recent occurrence. For Zulus, this dates back to at least the early 1900s when Isaiah Shembe, the Messianic Zulu evangelist, sought to introduce ancestor worship into the church (Brown 1999: 203). 
conclusion is that ancestral ecclesiology should be seen to possess and express the same "elements related to Christ's ancestorship such as universal kinship, beneficial mediation, exemplarity of conduct and frequent encounter with Him through regular devout prayer and ritual offerings, especially the Eucharist" (Nyamiti quoted in Magesa 2004:260).

Staples (1981:362-365) poses the question as to whether inculcating a contemporary scientific understanding of reality is a way of 'demythologizing' what he calls 'the Bantu (sic) world view'. One could simply declare that there are no ancestors, evil spirits, witchcraft or sorcery and that the whole African experience is a figment of their imagination and without objective reality; Staples states that this is not an adequate approach, because African Christians find their world view broadly corroborated in their reading of the Bible. In his theological response, Staples (1981:382) states that the Christian should not look to the ancestors for salvation, whether relating to earthly or to more spiritual concerns. He (1981:365-382) suggests, firstly, that a Christus Victor approach should be adopted. This, he claims, is a neglected theological emphasis. He quotes Sundkler who claims that Christ is the liberator from sickness, death and evil. Staples' (1981:382) second emphasis is on the Holy Spirit as a 'counterforce' to the malignant spirits of the African experience (cf Anderson 1991).

Magesa (2004:78) raises the issue of the 'dual religious consciousness' of most Africans. In the course of his research on inculturation, he discovered that, when dealing with cultural-religious issues, people experience an inner conflict between what he calls an 'unconscious' or instinctive behaviour, on the one hand, and the conscious cognitive response, on the other. The examples that he gives concern the issues of illness, marriage in relation to polygamy, and ancestors and spirits. He claims that even when the church does not approve of some traditionally African cultural-religious practices, people usually take instinctive personal or communal initiatives in dealing with an issue. The example is given of a retired Roman Catholic catechist who, after being widowed and having re-married, experienced troubling dreams said to originate from his first wife. The catechist thought that there was nothing wrong with performing a sacrifice in spite of the fact that his church did not approve of this and that he personally would have upheld this position during his ministry. Magesa (2004:79) poses the question as to what has moral priority in this case: the teaching of the church or the spiritual requirements of African religion. He concludes that there is a great deal of psychological and spiritual ambivalence in the practice of the Christian faith in Africa in relation to African cultural-religious practices.

From the above discussion, it transpired that there are many, and many opposing, views on the various aspects of salvation in the African and non-African context. Not only is the notion 'salvation' a complex one, but, as will be shown in the next section, the meaning of the term salvation is also complex.

\section{Linguistic Analysis of the Term, Salvation Salvation in the Old Testament}

In the Septuagint (the Greek translation of the Old Testament), sozo translates fifteen different Hebrew verbs. The two most important are yasa, used for 'to deliver and save', and malat, meaning 'to slip away, to escape, to deliver, to save' (cf, for example, 1 Sam 11:3). The noun soteria, which is common especially in Greek translation of the historical books, Job, the Psalms and Isaiah, stands for six different Hebrew formations and is used in a similar way to the verb yasa (namely to mean 'deliverance and salvation'). In what 
follows, the different Hebrew translations for salvation as it occurs in various contexts in the Old Testament are defined, drawing from Brown (1978:206-210).

Regarding the words sozo and yasa, deliverance is often used to show that it could be achieved humanly. It could be relief of a besieged city ( $\mathrm{cf} 1 \mathrm{Sam}$ 11:3) or help in battle (cf Judges 12:2f.; 13:5), although human agency does not preclude divine assistance. Israelite leaders, especially kings, had to deliver Israel (Judges 8:22; 1 Sam 3:18; 2 Kings 6:26; Hosea 13:10). The king was also seen as the deliverer of the poor and oppressed within the nation (Ps 72:4).

Secondly, Yahweh (the God of Israel) uses human agents, but deliverance comes ultimately from Yahweh Himself. The devout Israelite would believe this and would look both backward and forward to deliverance from both difficulties and enemies. The Psalmist would cry out 'Save!' or 'Help!' (Ps 12:1; 28:9; 60:5; 86:16; 69:1; inter alia). Deliverance or salvation from chaos at creation (Ps 65:58) and from historical enemies (Ps 60:11), along with His vindication and help, are all seen as the work of God. The exodus from Egypt is seen as Yahweh's greatest act of salvation: "Happy are you, O Israel! Who is like you, a people saved by the Lord, the shield of your hope and the sword of your triumph..." (Deut 33:29).

The word malat has a slightly difference in meaning to that of sozo; malat carries the meaning of 'slipping away or through' and of 'escaping' (cf Judges 32:9; 1 Kings 18:40; Zech 2:11). Two verses in which this word occurs are Ps 22:5 "To you they cried and were saved; in you they trusted, and were not put to shame" and Job 22:29f. "When others are humiliated you say it is pride; for he saves the humble".

The salvation expressed in the Old Testament is almost exclusively an earthly and historical one. The blessings are sometimes spiritual, and in certain passages there is an eschatological dimension (Is 45:22; 49:6).

\section{Salvation in the New Testament}

The verb sozo is found 106 times and the noun soteria 45 times in the New Testament. They are used in three different ways (Brown 1978:210-214). Firstly, they are used, infrequently, to mean "deliverance from immediate physical danger to life". Secondly, in the synoptic Gospels (i.e., Matthew, Mark and Luke), the verb sozo is often used in connection with the healing by Jesus of those who came to him, e.g., "Your faith has saved you" (Matt 9:22 par Mark 5:34; Luke 8:48). Here sozo carries the sense of "making well, deliverance from evil physical affliction".

Thirdly, in the proclamation of the early church, sozo and soteria gained a central importance through their application to Christ as the basis, content and goal of the gospel: "They are used to sum up the essential characteristic of his mission" (Brown 1978:214). Peter, the Apostle, declared to the Jewish leaders, "There is salvation in no one else, for there is no other name under heaven given among mortals by which we must be saved" (Acts 4:12). The apostolic teaching (kerygma) excludes all other ways of salvation and affirms that it can only be gained through Christ, by faith (cf Acts 16:31).

Jesus as a name is a form of Joshua who was God's agent of salvation for ancient Israel, whereas Jesus is God's Saviour from sin (Matt 1:21). The word salvation is used eschatologically, as in the story of Zacheus (Brown 1978:212-214): "And Jesus said to him, 'Today salvation has come to this house since he also is a son of Abraham, for the Son of man came to seek and to save the lost"' (Luke 19:9). 
Paul, the Apostle, reveals the goal of his ministry as bringing the good news of salvation to as many Jews and Gentiles as possible through preaching the gospel (Rom 1:15;11:14; 1 Cor $9: 22 ; 10: 33 ; 1$ Thess $2: 16)$. He was very aware that present and future salvation were closely related; according to Brown (1978:214), the very fact that Christians have already been saved makes the expectation of final eschatological salvation a greater certainty.

The rest of the New Testament emphasized the central place of salvation (Brown 1978:216). See, for instance, 1 Tim 1:15: "The saying is true and worthy of full acceptance that Christ Jesus came into the world to save sinners - of whom I am the foremost".

\section{'Save' in the Old and New Testaments}

Cruden's concordance of the Bible (Irwin, Adams, and Walters 1971:565-566) reveals that the verb, save, is used in a particular way in both the Old and New Testaments. The subject is usually the divine person, God or Jesus Christ, and the object is usually human. Old Testament examples include "Thus the Lord saved Israel that day from the Egyptians..." (Ex 14:30); “...the Lord does not save by sword and spear; for the battle is the Lord's..." (1 Sam 17:47); and "...that your way may be known upon earth, your saving power among all nations..." (Ps 67:2). Examples from the New Testament would be "For by grace you have been saved through faith and this is not your own doing; it is the gift of God" (Eph 2:8) and "...much more surely, having been reconciled, will we be saved by his life" (Rom 5:10b).

The definition of the word save, according to this concordance of Cruden, is (i) "to preserve from danger" and (ii) "to deliver from sin and its consequences". The concordance reveals that the term saved (ones) (of which the Zulu equivalent is abasindisiwe) is never used to designate Christians or describe their spiritual status. Rather, followers of Christ are described as 'disciples' in the gospels (Matt 10:1, Mark 5:31, Luke 6:13); they are also described as 'believers' (Acts 5:12, 11:21, 1 Tim 4:12). It was at Antioch that these disciples were first called 'Christians' (Acts 11:27). A common designation of the followers of Christ in the letters of Paul is that of 'saints' (Rom 1:7, 1 Cor 1:2, Phil 1:1, Col 1:2).

Accepting that all religions attach differing significance to salvation, it is important to clarify the distinctiveness of a specifically Christian approach to salvation. This distinctiveness lies in two areas: firstly, the life, death and resurrection of Jesus Christ and, secondly, the specific form of salvation, constituted by Christ. As mentioned before, it appeared that certain isiZulu-speaking Christians in the region in which the first author serves as priest have assimilated some of their cultural beliefs - namely the 'veneration' of ancestors - into their Christian beliefs and that, in reaction to this, other isiZulu-speaking Christians have added an extra meaning to the term salvation, namely a denouncement of certain apparently evil cultural practices, particularly those pertaining to ancestors. ${ }^{4}$ The next section contains a discussion of the methodology used to ascertain whether or not this was indeed the case.

\footnotetext{
Note that certain sectors of the isiZulu-speaking church require more than the denouncement of cultural practices pertaining to ancestors in order for a person to be deemed 'saved'; it is commonly known that in some denominations or congregations, there are dress code prohibitions, particularly for women (for example, saved women do not wear trousers, jewelry or make-up), and also dietary prohibitions (such that saved ones do not eat pork products). Whereas we acknowledge that these prohibitions are also central to some isiZuluspeaking Christians' definition of salvation and insindiso, the focus in our study is on those prohibitions related to the ancestors, as it appeared to us that the latter prohibitions were those causing the most disagreement among the Zulu Christians with whom we have contact.
} 


\section{Research Methodology \\ Data collection}

A questionnaire on matters pertaining to salvation and the English and isiZulu terms associated with it was devised to assess the perceived differences between and the connotative meaning of various terms. This questionnaire formed the basis of semistructured interviews with nine mother-tongue speakers of isiZulu. The questionnaire comprised the following 10 questions:

1. Uqondani umuntu uma ethi 'Ngisindisiwe'?

What does a person mean when he/she says, 'I am saved'?

2. Nkokucabanga kwakhe lithini iBhayibheli ngendaba yokusindiswa?

In your opinion, what does the Bible say about being saved?

3. Ngabe leli gama elithi, ukusindiswa linemiqondo ehlukene yini kumaKristu?

Does the term to be saved have different meanings amongst Christians?

4. Uma linemiqondo ehlukene, umehluko ukuphi?

If there is no single meaning, what are the differences?

5. Yini eyenza amaSheshi namaRoma angalithandisisi kahle leli gama loku sindiswa? What causes Anglicans and Roman Catholics not to like the term to be saved?

6. Abangasekho (amadlozi) abenzelani abantu abangamaZulu nabaseAfrika bonke? What do the ancestors do for African people, especially isiZulu-speaking people?

7. Ngabe amadlozi asebenza ngokufanayo yini kubantu abangamakholwa nalabo abangakholwa na?

Do the ancestors function in the same way for both believers and non-believers?

8. Kungani indaba yabangasekho amakholwa engayikhulumi nje obala?

Why is it that many (Christian) believers do not speak openly about the ancestors?

9. Likhona yini igama elingcono kunaleli loku sindiswa elingasetshenziswa ukuze kunciphe ukwehlukana phakathi kwamaKristu na?

Is there a better term than to be saved that will lessen division amongst Christians?

10. Ukhona yini umehluko ekusebenziseni igama lokusindiswa phakathi kwabamhlophe nabamnyama na? Uma ukhona uchaze.

Is there a difference in the way white and black people use this term? If there is, please explain.

Four of the interviews were conducted in isiZulu, as these four interviewees were not very proficient in English, and using isiZulu enabled them to express themselves in words that are an integral part of their culture. Those who agreed to be interviewed in English were highly proficient in English; they did, however, occasionally make use of code switching in order to express themselves more clearly.

The interviews were all conducted privately with no one else present. An explanation was given as to the purpose of the interview and no one who was approached refused to be interviewed, even though the subject was of a fairly controversial nature, which could have involved some perceived risk to those participants who were members of the first author's parish. 


\section{The Participants}

The research necessitated that the interviewees be mother-tongue speakers of isiZulu. They were chosen with the specific intention of covering a reasonably wide spectrum of opinion. The characteristics borne in mind during participant selection were age, church affiliation, and level of theological literacy. Nine participants (six males and three females) were selected; reasons for the limited number of participants are that the study is exploratory in nature and that the interviews were semi-structured and as such rendered lengthy answers (indeed, more discussion than mere question-answering took place) which had to be transcribed verbatim, a laborious process. Participants ranged in age from 24 to 63 years; six were Anglican and three non-Anglican; five were theologically literate whereas four had no formal theological training. There were three clergy and six lay people. A summary of participant characteristics appears in Table 1. All the participants were previously known to the first author and resided in the geographical area in which he worked as priest.

Table 1. Summary of characteristics of the 9 participants

Table 1. Summary of characteristics of the 9 participants

\begin{tabular}{|l|l|l|l|}
\hline $\mathbf{I}$ & Denomination & Theological training & $\begin{array}{l}\text { Approxi- } \\
\text { mate age }\end{array}$ \\
\hline $\mathrm{Ms} \mathrm{AB}^{\mathrm{a}}$ & Zionist & None & $20 \mathrm{~s}$ \\
\hline $\mathrm{Ms} \mathrm{CD}^{\mathrm{a}}$ & Methodist & None & $20 \mathrm{~s}$ \\
\hline $\mathrm{Ms} \mathrm{GH}^{\mathrm{a}}$ & Anglican & None & early 40s \\
\hline $\mathrm{Mr} \mathrm{EF}^{\mathrm{a}}$ & Anglican & None & $60 \mathrm{~s}$ \\
\hline $\mathrm{Mr} \mathrm{IJ}^{\mathrm{b}}$ & $\begin{array}{l}\text { Anglican (with Roman } \\
\text { Catholic background) }\end{array}$ & $\begin{array}{l}\text { Catholic Seminary, for 5 years. (Mr } \\
\text { IJ is not yet ordained in the } \\
\text { Anglican church; for that to take } \\
\text { place, he will have to receive } \\
\text { further training as an Anglican). }\end{array}$ & $30 \mathrm{~s}$ \\
\hline Mr KL $^{\mathrm{b}}$ & $\begin{array}{l}\text { Anglican (with Pentecostal } \\
\text { background) }\end{array}$ & $\begin{array}{l}\text { Bible College, for three years full- } \\
\text { time. }\end{array}$ & $40 \mathrm{~s}$ \\
\hline Pastor MN & African Evangelistic Church & Ordained pastor & $50 \mathrm{~s}$ \\
\hline Rev OP $^{\mathrm{b}}$ & Anglican & Postgraduate (PhD in Theology) & $50 \mathrm{~s}$ \\
\hline Rev $\mathrm{QR}^{\mathrm{b}}$ & Anglican & $\begin{array}{l}\text { Ordained (after completing a formal } \\
\text { course in theological studies) }\end{array}$ & $50 \mathrm{~s}$ \\
\hline
\end{tabular}

${ }^{a}$ Interview language isiZulu; ${ }^{\mathrm{b}}$ Interview language English. ${ }^{\mathrm{c}} \mathrm{Mr}$ IJ was raised Roman Catholic and was intent on becoming a Roman Catholic priest. However, a problem arose which prevented him from being ordained, after which he decided to become an Anglican and was received into membership of the Anglican Church. ${ }^{\mathrm{d}} \mathrm{Mr}$ KL was raised Pentecostal and his theological training was Pentecostal. After completing this training, he decided to become an Anglican and was received into membership of the Anglican Church.

\section{Data Transcription and Analysis}

The nine interviews were audio-recorded and later transcribed orthographically. The isiZulu parts of the interviews were then translated into English. The responses to question groups (Questions 1-2, 3-5, 6-8, 9, and 10) were then collated and analyzed qualitatively, in order to inform the research question. The analysis was carried out within the framework of 
Bolinger's (1980) exposition of so-called loaded words, to which we return later. The patterns and themes found in the responses to the various question groups were identified. The results of this analysis are presented in the next section and discussed in the section thereafter.

\section{Results}

\section{Questions 1 and 2: The meaning of to be saved in general and according to the Bible}

The first two questions of the questionnaire aimed to clarify the interviewees' personal understanding of the term to be saved, including their knowledge of the biblical use of the term. All but one person answered by referring to the inner change that happens in people who are said to be saved. Five interviewees used the phrase (to) separate (themselves from sin or evil) in their answer to Question 1, implying what clearly emerges later in the interviews, namely that to be saved, a person would cut him/herself off from certain beliefs and practices deemed inappropriate for the saved. For example, in this regards, Ms AB said: "The Bible says that you must leave behind everything that is of the world; other gods and everything that you did and then you must serve God."

In answering Question 2, several interviewees quoted Bible references, the most common being Matt 1:21 which says that Mary's son was to be named Jesus, "for he will save his people from their sins". Those without theological training spoke mostly in general terms about how the Bible requires people to believe and trust, and about the need to live a lifestyle in keeping with one's profession of faith. For example, Ms CD said, "Eh, on the matter of being saved, the Bible tells us a lot. If we read the Bible, we hear that to be saved, a person who is saved no longer associates with other people. We [black - NK\&FS] people, when we think of this word, we think of separating ourselves."

Only the theologically trained spoke clearly about salvation as being God's work. For instance, Rev OP said, "He is coming to provide salvation for humankind, so for me that is where the whole thing begins. The mission of Jesus Christ is that of bringing about wholeness, salvation, well-being to the world, to every human being." By contrast, those without theological training emphasized the common perceptions about saved people and what they do; for example, Ms CD said, "Eh, I myself think that if a person says s/he is saved, $\mathrm{s} /$ he means that $\mathrm{s} /$ he has accepted Jesus. She is born again. It happens that you get a person who is living a life that is not right. S/he is doing things that are not proper/fitting. God does not like them. If $\mathrm{s} / \mathrm{he}$ has separated him/herself form all those things, $\mathrm{s} / \mathrm{he}$ is saved, s/he is living a new life, s/he has left the evil that $\mathrm{s} /$ he is doing. I think it means something like this."

One interviewee, Ms GH, did not answer the question directly but expressed her disapproval of the way the 'saved people' behave towards people like herself, who are deemed not saved and who come from traditional churches. When asked, "What does a person mean when s/he says, 'I am saved?", she immediately responded with "Uqonda ukuthi unokukholwa okuncono kunokwami, engingasindiswanga [S/he means that her/his belief is better than mine, because I am not saved - NK\&FS]." 


\section{Questions 3, 4 and 5: Different interpretations by different Christians}

of the term to be saved

The answers to Question 3 were somewhat varied, but mainly emphasized the broad differences between people from traditional churches, on the one hand, and abasindisiwe ('the saved ones') and Pentecostal churches, on the other. Those who are saved do not 'do' certain things, some mentioning that these prohibited activities include cultural practices. For example, Ms AB said, "The difference between these Churches is that the saved, they have this, that the departed, it is finished with them. In other congregations, you find that they believe that people who have died still live with them, even though they are not with us. These are the different meanings of this thing about being saved." Mr IJ introduced the concept of the 'ownership' of the term to be saved, saying, "Pentecostals think salvation belongs to them, because usually they go around telling people that, 'I have been saved, and I am not doing this and that'." He also said, "They think it's their word, salvation is theirs, ukusindiswa kungokwabo ['to be saved/salvation is theirs' - NK\&FS], and no one else can be saved. They go around, it's like boasting."

The contested nature of the term began to come to the fore in answers to Question 3, as an element of resentment emerged that certain churches use the term in an exclusive and apparently judgmental way. In this regard, consider the response of Ms GH: "The difference is that, if you say you are saved, in that way you are telling me that your belief is better. You are full of criticism."

Answers to Question 4 revealed further emphasis on the judgmental attitude of abasindisiwe and of the negative attitudes to culture of abasindisiwe. For example, Mr IJ said, "There is that difference between us and them. Sometimes when you go to these churches, Pentecostal churches, you will feel that you are not welcome, because people will stand there and boast saying Jesus Christ is their Lord, and what is a visitor is going to say now? Instead s/he will just sit down and not say anything."

Question 5 is where many of the interviewees revealed their dissatisfaction with the term. To a greater or lesser extent, all the interviewees maintained that, according to abasindisiwe, the issue of ancestors defines one's status as either saved or not saved. Those interviewees who are personally more comfortable with involvement in ancestral practices spoke in resentful terms of those who are abasindisiwe and those who adopt a condemnatory attitude to others. They particularly resent the assumption that anything cultural is bad and that the ancestors who they hold in high esteem are condemned as demonic, which is seen as the ultimate insult for people who revere their ancestors. In this regard, Ms AB said, "I see that they speak badly about the ancestors, the saved ones, especially that if you worship the ancestors, you are worshiping the idols and all that." Ms CD said, "It happens that these are Churches that say they are saved; they don't sacrifice to the ancestors, they don't believe in the ancestors. They speak badly of our culture and customs, we Roman Catholics and Zulus, because we praise the departed." Rev OP said, "I think the superior kind of mentality that or ... how can I put it? The way those who claim to be saved come across to Anglicans and Catholics and others, is very offensive in that they come claiming to be better Christians than them. And I think it does offend other people who are actually doing their best to serve God within the parameters of what they understand; to get someone else coming and saying to them, 'You are not saved, because of this and this'. And I think that is what really offends many Anglicans."

Those who are more inclined to an evangelical theological position (Mr KL, Rev MN, Rev OP, Rev MN and Pastor QR) do have strong opinions on the inappropriateness of ancestral practices but also maintain strongly that abasindisiwe are insensitive to this 
subject of culture and ancestors, which is an integral part of the community life of most isiZulu-speaking people. In this regard, Mr KL said, "It is a word which has been used in many situations and the writings of the main-line churches and in charismatic churches you will find it used. But we must use it properly - not to bash other people with it." Most of the interviewees agreed that the difficulties associated with the term to be saved are exacerbated by a condemnatory and judgmental attitude of abasindisiwe.

\section{Questions 6, 7 and 8: Opinions on ancestors}

These questions were designed to clarify the role and reveal the significance of the ancestors in the lives of people in the isiZulu-speaking community in relation to the term to be saved. Those interviewees who were involved in ancestral practices at the time of the interview, spoke about the importance of their ancestors to them and of how intimately involved the ancestors are in their lives - how they guide, protect, intercede, mediate and provide for their people in very practical ways. For example, Ms AB said, "Eh, I myself say that is my belief, I believe that they protect me. Even when I am in an accident, I am protected. They give me good fortune and many other things and even if I need a job, I will find it because of them" and Ms CD said, "A person who does good things on earth, then becomes an ancestor, does s/he do good for those who are left behind? Mm, now how is one blessed by an ancestor? What do they do for one? Mm, they bring good fortune or they get work for you."

Some interviewees argued from a theological position that culture and religion are inseparable. In this regard, Mr IJ said, "For me personally, I believe that when God created us, he made us have different cultures. For example, I am a Zulu person; the whole of my background is for a Zulu. I grew up as a Zulu. We Zulus have got our own cultures. We keep our own cultures. We honour the dead, we slaughter for them. And there are people who are not Zulus, like coloureds, whites and Indians; these people also, each race has got its own culture s/he is keeping. Like some people, they go to a grave and place flowers on the grave, to remember and honour their fathers and mothers, because I believe that I have got a person like my mother and my father who raised me in a good way." Also consider in this regard Mr EF's statement that "we have grown up with traditional customs as Jesus did traditional things as well."

Those who approve of ancestral practices emphasized the need to separate these "issues of home" from 'church matters'. This is the reason given for congregants not bringing the issue of ancestors to church. For example, Ms AB said, "I see that it is an important matter of the home, not something you preach about. What is important is that we worship/serve the ancestors at home; when we are at church, we worship/serve God."

Those who do not approve of ancestral practices were divided as to whether the ancestors wield real power or whether they are part of superstitious views of life. For instance, Rev QR said, "Well, frankly, they don't do anything for them. Amadlozi ['the ancestors' - NK\&FS] do not do anything for the people who are the Zulus. But in as far as religion is concerned, it helps them to cope with life, to cope with issues, to cope with things that are too difficult for them to comprehend or understand. And they make an appeal to their ancestral spirits for comfort", whereas Past MN said, "I would say the spirit of amadlozi is real and this is a spirit." He continued, "This ancestral thing is a devil thing. You know, I was once a sangoma, before I became a Christian. I know all about their practices and lot of things in their world." 


\section{Question 9: Alternatives for the term to be saved}

It has been noted that most of the interviewees have agreed on the need for greater sensitivity in the use of language and in the attitude of abasindisiwe toward other church groupings. Most of those who felt threatened by the use of the term abasindisiwe would like a term other than the one in question to be used. The exception was Mr IJ, who wanted the more traditional churches to stake their claim to this term. In keeping with this attitude, he believed the term should be rehabilitated rather than finding alternative terms: "So we need to rehabilitate this word, not let anyone own this word, but let everyone own this word". Most of those interviewees who believe in the importance of salvation wanted the term to be rehabilitated and for it to continue in use, but with a better understanding of it among church people of various denominations. For example, Rev OP said in answer to the question as to whether there is a better term, "I don't think there is, and even if we can come up with the new one, I don't think it would actually make any difference. Because as it deals with the same questions, I think it would still land us where we are. I think for me is finding ways of actually talking about the same thing, but communicating in such a way that people are able to understand what you are saying. When you talk about those issues of salvation, do not be judgmental to people or make them feel that because they still believe in ancestors ... I think it is the attitude of being judgmental that offends people, in such a way that they want to close their ears when you talk."

\section{Question 10: Different interpretations by white and black Christians of the term to be saved}

There was a definite difference of opinion in the answers to Question 10. Some interviewees believed that because of the cultural issues implied in the use of the phrase to be saved, there was a distinct difference in the way the term is used by black and white people. These opinions tended to be from those who were more sympathetic to ancestral practices. For example, Mr EF said, "Maybe their belief is not the same as ours. Maybe they do not have customs like us. If a black person tells me that $\mathrm{s} /$ he is saved, I know that $\mathrm{s} / \mathrm{he}$ is against the departed." Ms AB said, "Yes, I see a difference because black people, they are the ones who use it a lot. I have never heard a white person say, 'I am saved."'

In contrast, those interviewees who were less sympathetic to ancestral practices did not feel there was a difference in the way the term was used. Mr KL was ambivalent. He said, "There should be no difference in its use by black and white people because all need to be saved from our sins and the wrath of God. There is a difference, however, because black people often associate it with the need to disassociate themselves from ancestors." Rev QR said, "Well, there is no difference. I happen to serve in both black and white communities. I don't think the term is used differently. In both cultures, it is used to denote a difference between just having faith in God or believing in any god and the God who is able to influence us and the God that is able to change our lives and a God that is able to have a personal relationship with us. The word saved to both black and white begs the question that follows, 'Who saved you?' and it would have been this God who can do something for me in space and time... If I just say, 'I believe', it does not necessarily say, 'I have any relationship with God', but if I say 'I am saved', it means complete reliance on God." 


\section{Discussion}

\section{To be 'saved/ukusindiswa' can be a loaded term}

Bolinger (1980:68-87) maintains that language is seldom neutral and that it can be used in an extremely biased way. Words can pick up an extra 'ingredient' of semantic material when moving from one context to another. This ingredient can be irrelevant to the central meaning of such words. Bolinger (1980:72) gives the example of units of measurement: hands for horses, fathoms for water depth, and knots for speed on water. In each case, there is an assumed association, which is the extra 'ingredient' referred to by Bolinger.

This assertion of Bolinger's is applicable to the terms under consideration. The interviewees expressed the opinion that to be saved/ukusindiswa has, in certain senses, picked up such an extra ingredient. These terms have been appropriated by a particular ecclesiastical grouping in the geographical area concerned, which - by adding an extra ingredient - has narrowed the meaning of the terms. The conventional linguistic and theological meaning of salvation is already a 'complex notion' (McGrath 1997:386-420). The more recent, narrower meaning of the term, as used by certain isiZulu-speaking Pentecostals and Evangelicals (the so-called abasindisiwe), implies and assumes an exclusive, specific, validating spiritual experience which then precludes any involvement with ancestral practices. Consequently, one is viewed as being saved only if one denounces certain evil cultural practices, particularly those pertaining to ancestors. According to some members of these latter church groupings in the geographical area in question (and possibly outside of this area as well), the narrower meaning of salvation is the only correct one, and therefore, in their opinion, their use of the term is the only legitimate one. This type of semantic change is called 'semantic narrowing', defined by Nordquist (2008) as "the process by which a word's meaning becomes less general or inclusive than its earlier meaning". This narrowing of meaning is similar to the one that hound underwent: In Old English, hound (then hund) meant '(any breed of) dog', whereas in Modern English, hound refers to a particular breed of dog (Shukla and Connor-Linton 2006:285). However, whereas the meaning of the English word hound narrowed on a global scale, the meaning of to be saved/ukusindiswa has not undergone such wide-spread change: white Englishspeaking Christians are in general unaware of the semantic narrowing in this case, and some black isiZulu-English bilinguals who are aware of the narrowing disapprove and use salvation as having its original, broader meaning also found in and confirmed for them in An Anglican Prayer Book 1989/Incwadi Yokukhuleka YaseSheshi 1989.5

\footnotetext{
The most frequent form of the root word save occurring in An Anglican Prayer Book 1989 (35 times) is the word salvation, used, amongst others, in the following different ways: salvation in Christ Jesus (p. 282), Readings); giver of health and salvation (p. 502 par. 29) and the salvation of humankind (p. 190 par. 54). Saviour is the second most used form of the root word save in An Anglican Prayer Book 1989 (24 times), as in the following: most merciful Saviour (p. 541 par. 26); Saviour of the world (p. 77 par. 9) and their King and Saviour (p. 175 par. 25). Another use of the root word save is seen in the word saving, which describes the action or work of Christ, as in the following examples: Christ's saving victory (p. 18 par. 1); your saving love (p. 264, collect) and his saving grace (p. 399 par. 101). The word save itself is also used predominantly in the Lord's Prayer, which is repeated thirteen times in many different parts of the prayer book - save us from the time of trial (p. 49 par. 24, for example). Other ways in which the word save is used include you delivered and saved the world (p. 170, collect); he saved the human race (p. 182 par. 36) and saved through Christ for ever (p. 588 par. 39). The translation from English to isiZulu is consistent throughout the isiZulu version of $A n$ Anglican Prayer Book 1989, namely Incwadi Yokukhuleka Yasesheshi 1989: salvation is translated as insindiso; Saviour as Umsindisi; saving as sindisayo; save as sindisa; and saved as sindisiwe.

It should be noted at this point that certain Anglican prayer books contain reference to not only salvation, but also ancestors. Bediako (1995: 229) mentions that in the (Anglican) Church of the Province of Kenya's A Kenya Service of Holy Communion (1989), there is a prayer giving thanks for the lives of the departed in
} 
As was shown previously, salvation is a multi-faceted concept; and the term salvation and related ones are equally complex. Some interviewees felt that the narrow meaning of this term is discriminatory against those who honour their ancestors in the traditional ways, and that this term is used to denigrate them as members of traditional churches or as people for whom the cultural practices concerning ancestors are important. According to the interviewees, the use of this term emphasizes the fact that the abasindisiwe perceived their own faith as being superior to that of members of traditional churches. The use of the term abasindisiwe ('the saved ones') has therefore become the name given by some to an ecclesiastical grouping within the broad church context, which perceives itself as being qualitatively superior to other groups. As was pointed out by $\mathrm{Mr} \mathrm{IJ}$, this is reflected in an attitude of the ownership of this term by abasindisiwe. What used to be a term referring to the redemptive work of God in the history of the Jewish people, culminating in Christ's life, death and resurrection and looking forward to his parousia at the end of time, has, due to selective semantic narrowing, become a loaded term referring, for some, to a certain spiritual experience of a particular ecclesiastical grouping.

Bolinger (1980:86-87) also draws attention to the use of the passive voice which, he claims, is more open to bias than the active voice. He gives as example The reports were handed in (from which the agent, students, is omitted) versus The students handed in the reports (in which the agent is expressed). As stated by Bolinger, there is nothing deceitful about omitting the agent per se. In fact, it is useful if the agent is already known or if it does not matter. However, bias enters when the passive is used to conceal the agent. Furthermore, some implicit passive constructions lack a normal place where the agent might be revealed, as can be seen in the sentence He is one of the chosen. It would be natural to ask, 'Chosen by whom?' However, if He is one of the elite is said, a superiority free of any granting agent is assumed. The hearer is invited to suppose that it is by heredity or by divine grace (Bolinger 1980:86-87).

These examples of Bolinger are directly relevant to the first question in the interviews, namely "what does a person mean when s/he says, 'I am saved?"' When using the word saved, the Bible seldom, if ever, uses the passive form. This is also true of An Anglican Prayer Book 1989/Incwadi Yokukhuleka YaseSheshi 1989. The conclusion, therefore, is that the term saved/sindisiwe is at times used in a biased manner with the agent of salvation omitted or relegated to seeming irrelevance, in such a way that the focus is on the recipient of this status. This further emphasizes this status as being superior, and subtly shifts the emphasis onto the recipient rather than the provider, who in this case is God.

Christ which reads: "Gracious Father we heartily thank you for our faithful ancestors and all who have passed through death to the new life of joy in our heavenly home. We pray that surrounded by so great a cloud of witnesses, we may walk in their footsteps and be fully united with them in your everlasting kingdom." Later in the service, the introduction to the Sanctus reads: "Therefore with angels and archangels, faithful ancestors, and all in heaven, we proclaim your great and glorious name..."

Also in the Catholic publication The Sunday Missal (1977), terms related to salvation occur frequently. For instance, salvation occurs 186 times, save 108 times, saved 67 times and saving 48 times. Examples of such occurrences include the salvation you won for us (p. 277, Opening prayer), bring us salvation (p. 291, Prayer over the Gifts), save us, Lord our God, and gather us together from the nations (p. 291, Entrance Antiphon), you will all men to be saved (p 829, Opening Prayer) and let your saving love grow within us (p. 326, Prayer after Communion). 


\section{The Term cannot be used Interchangeably in Different Cultural and Linguistic Contexts}

As was shown previously, one of the implied meanings is that abasindisiwe do not engage in ancestral practices and that this kind of Christianity (that of the abasindisiwe) is hostile to culture generally. White people use the term to be saved without knowledge of the implied meanings in the isiZulu-speaking context. ${ }^{6}$ Some IsiZulu-English bilingual hearers may assume that the white English-speaker shares their understanding of the term and its (narrow) underlying meaning, which could result in intercultural miscommunication.

In Kaschula and Anthonissen (1995:83-86), a lack of equivalence between the English word foster and its closest isiXhosa translation resulted in intercultural miscommunication in a legal setting, with adverse effects. In contrast to adopt or foster and ukondla/ukukhulisa (the latter which would best be interpreted as 'maintaining' or 'causing to grow'; Kaschula and Anthonissen 1995:86), to be saved and ukusindiswa both mean the same to Englishspeaking Christians, and they both mean the same to isiZulu-speaking Christians. However, the meaning held by the isiZulu-speaking Christians is only in some cases equivalent to that held by the English-speaking Christians. For some isiZulu-speaking Christians, the meaning of the terms has narrowed, so that they now cannot be used in all the contexts in which the terms can be used according to English-speaking Christians. This is grounds for intercultural miscommunication of a complex nature.

\section{Conclusion}

This research was conducted in order to ascertain whether there is a possibility of intercultural miscommunication and resultant division between Christians pertaining to the use of the term to be saved/ukusindiswa by particularly isiZulu-speaking Christians. The specific research question was whether or not the meaning of the term to be saved/ukusindiswa is unambiguous and could possibly lead to intercultural miscommunication. The wide disparity in the use if the term can be highlighted in the response of Ms GH who said, "Our customs go a long way, they are very deep. Therefore I must not say, 'I am saved'; even my ancestor does not like it when I say 'I am saved', because he knows what I mean. If a person says s/he is saved, if you tell him/her about the ancestor, $\mathrm{s} /$ he will tell you that you are speaking about demons. By that time I have become very angry." This is in contrast to Pastor MN's comment that he was a sangoma before he became a Christian and is of the opinion that "this ancestral thing is a devil thing ... So, you can't combine Christianity and ancestral worship." These two responses could be representative of two of the contrasting ways in which the church in Africa has responded to the issue of ancestors. The first way is that of attempting to incorporate the African world view into the church and into the lives of individuals, in particular making space, theologically speaking, for the ancestors. This represents an attempt at rectifying the intercultural miscommunication of the past, which came about, amongst other reasons, because the African culture and the African world view were not sufficiently understood by the early missionaries in order to present the Christian message in a manner which integrated the context with the message. This could be said to be a failure in intercultural communication, the effects of which are being widely felt today and which have given occasion to this study.

This observation we make on the basis of our interaction with white Christians in general and with the white members of the first author's parish in particular. 
The second manner in which the church has responded to the issue of ancestors is to view the incorporation of the ancestors as a form of syncretism which should have no place in the church. Proponents of this view would claim that to incorporate the ancestors would be to misunderstand the biblical message, leading, in effect, to a form of intercultural miscommunication between the Bible, the church and contemporary society.

This study has highlighted the fact that in the Christian church in Africa and in the isiZulu-speaking community in particular, the issue of salvation and the use of the terms salvation, to be saved and their isizulu equivalents are possibly complex and controversial. The meaning of both the English and isiZulu terms has undergone selective semantic narrowing in some cases, which is not approved by all isiZulu-speaking Christians in the different ecclesiastical cultures and of which mother-tongue speakers of English are generally not aware. The contested and, at times, divisive nature of the term - resulting from a misunderstanding of the biblical concept and from miscommunication between particular groups within the Christian church - has been highlighted. This was done to raise awareness of the different meanings of the English and isiZulu terms and to make a limited yet meaningful contribution to improved communication between Christians from different denominational cultures.

Given the vast number of denominations and the fact that views on salvation and the particular meaning attached to the terms in question may differ greatly from one congregation or parish to the next even within the same denomination and the same geographical area, we acknowledge that our findings have limited generalisability. In order to increase this generalisability and to obtain a more complete picture of the divisions pertaining to these terms found in the Church at large, it is recommended that interviews of the type employed in this study be conducted with a larger group of Christians, increasing the age range and denominational backgrounds of the participants. Furthermore, interview data should be supplemented by direct observation of revival meetings, vigils for the deceased, and church services and small group meetings held by members of the various denominations. This should render a larger body of data from which to analyse the potential problems of different meanings attached to the same terms. 


\section{BIBLIOGRAPHY}

An Anglican Prayer Book 1989. Jeppestown: Harper Collins.

Anderson, A 1991. Moya. The Holy Spirit in an African context. Pretoria: UNISA.

Bediako, K 1995. Christianity in Africa. The Renewal of a Non-Western Religion. Edinburgh: Edinburgh University Press.

Boff, L 1978. Jesus Christ liberator: A critical Christology for our time. New York: Orbis.

Bolinger, D 1980. Language - the loaded weapon. The use and abuse of language today. London and New York: Longman.

Brown, C (ed.) 1978. The new international dictionary of New Testament theology. Grand Rapids, Michigan: Zondervan Publishing House.

Brown, D 1999. Orality and Christianity: The Hymns of Isaiah Shembe and the Church of the Nazarites. In D Brown (ed.) Oral literature and performance in Southern Africa. Oxford: James Currey; Cape Town: David Philip; and Athens, Ohio: Ohio University Press.

Holy Bible. New Revised Standard Version 1997. London: HarperCollins Publishers.

Gerloff, R (ed.) 2003. Mission is crossing frontiers: Essays in honour of Bangani Mazibuko. Pietermaritzburg: Cluster Publications.

Incwadi Yokukhuleka Yasesheshi 1989. Johannesburg: HarperCollins Publishers.

Irwin, $\mathrm{CH}, \mathrm{AD}$ Adams, and SA Walters (eds.) 1971. Cruden's complete concordance to the Old and New Testaments (New revised version). London: Lutterworth Press.

Kaschula, RH and C Anthonissen 1995. Communicating across cultures in South Africa. Towards a critical language awareness. Johannesburg: Witwatersrand University Press.

Magesa, L 2004. Anatomy of inculturation. Transforming the church in Africa. Maryknoll, New York: Orbis Books.

Mana, K 2002. Christians and churches of Africa envisioning the future. Salvation in Christ and the building of a new African society. Carlisle: Paternoster Publishing.

McGrath, AE 1997. Christian theology. An introduction (Second edition). Oxford: Blackwell Publishers.

Meiring, P (ed.) 1996. A world of religions (A South African perspective). Pretoria: Kagiso Publishers.

Mukuka, G. The impact of Black Consciousness on Black Catholic clergy and their seminary training. http://www.sorat.ukzn.ac.za/theology/bct/vat8.htm - accessed 8 June 2009.

Nordquist, R 2008. Semantic narrowing. Available online at http://grammar.about.com/od/rs/g/semnarrterm.htm. Accessed 1 October 2008.

Shukla, S and J Connor-Linton. 2006. Language change. In RW Fasold and J ConnorLinton (eds.) An introduction to language and linguistics. Cambridge: Cambridge University Press.

Staples, RH 1981. Christianity and the cult of the ancestors: Belief and ritual among the Bantu-speaking peoples of Southern Africa: An inter-disciplinary study. Unpublished doctoral dissertation. Princeton Theological Seminary, Princeton, New Jersey.

The Sunday Missal 1977. London: Collins Liturgical Publications. 